\title{
British Universities and Government Establishments
}

\author{
Two years ago the Council for Scientific Policy appointed a working \\ party to consider ways of achieving closer collaboration between \\ universities and government establishments. The committee, \\ under Sir Gordon Sutherland, has found the establishments to be \\ more willing partners than the universities.
}

THE view that government research establishments would welcome a much closer relationship with universities is one of the principal conclusions of the Sutherland committee on liaison between universities and government establishments. The committee, however, is less certain that the universities are ready for a closer relationship. "Opinion is not quite so definite in the universities . . . and at present only a minority of the universities appear to us to be willing to take a strong initiative in this matter." The committee says, by way of oil on potentially troubled waters, that the diffidence of the universities is understandable because the advantages of collaboration are usually more obvious to the government establishments. The committee says that some universities are afraid that their research work would be "weakened" by some of the proposals that it has been discussing.

The Sutherland committee was set up by the Council for Scientific Policy in April 1965. Its members are Sir Gordon Sutherland, Dr. A. H. Cottrell, Professor K. C. Dunham, Professor E. B. Chain, and Professor R. V. Jones. Its scope allowed it to consider practices in all government research establishments, including those of the research councils and the Atomic Energy Authority. The working party set out deliberately to collect information about the degree of collaboration, and in particular circulated a questionnaire to universities, with the collaboration of the University Grants Committee which undertook to solicit replies and analyse them.

\section{Opportunities}

The underlying theme of the report is that there are at present many neglected opportunities for collaboration between government laboratories and universities. It singles out five principal ways in which more might be done-closer staff relationships, co-operative research projects, formal association of research establishments with universities, recognition of establishment research for higher degrees, and easier mobility in transfer for people. Evidently much of what the committee has to say will bear on discussions such as those by which the Fulton Commission will eventually recommend what should be done about the Civil Service.

The committee says that " $a$ considerable majority" of government establishments would like to see some members of their staffs given university status and university titles so that they could spend some of their time lecturing, supervising students and "taking some part in the discus. sion of university policy on research and advanced teaching". Something along these lines is at present being done at twenty universities, although most existing arrangements are concerned with the staff of research units established by the Agricultural and Medical Research Councils. The committee commends the way in which the universities of Strathclyde and Birmingham have set up close collaboration with the National Engineering Laboratory and the Royal Radar Establishment respectively, says that academic status seems to be a harbinger of closer collaboration in research, recommends that both universities and government establishments should consider ways of strengthening collaboration, and argues that when new government research establishments are created they should be sited near a suitable university.

On co-operative research projects, the report says that the establishments at present subsidize by means of extra. mural contracts roughly $£ 1.9$ million of research a year in universities. Its enquiries have, however, revealed that universities are usually unwilling to accept these contracts unless they are for work which fits well with research already under way. The committee thinks that there is more that can be done and has apparently been particularly attracted by the way in which the Swedish Government is able to initiate research work at universities in fields of national importance by creating research groups which are in due course taken over by the universities. The committee thinks that government departments must take the initiative in this field and it urges them to make specific proposals for co-operative research projects with appropriate universities.

\section{Collaboration}

A more radical vehicle for collaboration is the formal association of a research establishment with a university. It is particularly attracted by the way in which the United States government has set up research centres near universities and has delegated to the universities responsibility for their operations. The Sutherland committer argues that this arrangement gives university staff and research students a valuable insight into research of national importance without leading to government control of academic research because "participation in the work of the establishment is voluntary". But the Sutherland committee is clearly aware that this is a thorny issue and it recommends that arrangements like these should be studied in greater depth by the Committee of Vice-Chancellors and Principals and by government departments to see whether Britain can make use of precedents established elsewhere. On the awarding of higher degrees, the Sutherland committee points out that there is at present no uniformity of policy among the universisities and "even within a single university towards different establishments". It is, however, full of admiration for the way in which the University of London has designed new academic regulations which make it possible for people to read for $\mathrm{Ph}$.D. degrees while working at government establishments. Under the new arrangements, the university is responsible for seeing that supervision is satisfactory, while candidates for higher degrees are given a "real contact" with the university. The committee rejects the fear that an extension of these arrangements to other universities would mean that the universities would be denuded of research students. The argument is that if a student can earn a full-time salary as a member of a research establishment and still read for his degree, he is unlikely to be satisfied with the usual 
student's grants. Tho committee's reason for thinking otherwise is that only a small part of the work at an establishment can lend itself to Ph.D. work, so that the student turned civil servant will nearly always have other things to do. But then there is the problem of writing a thesis in private time, the fact that "the more academically inclined will always prefer to spend all their time in a university", and the fact that government research establishments have a limited capacity to absorb students. Altogether, the committee thinks that the government establishments would not be able to absorb more than 150 potential Ph.D. candidates a year, or less than 7 per cent of those at present graduating with Ph.D.s in science, engineering and technology from British universities.

\section{Establishments}

The argument that scientific people should be able to move more easily from and into government establishments has been a steady chorus for some years now, and the Sutherland committee has lent its own support. It says that pension arrangements are often quite different in the universities and the research establishments, which means that easy movement is discouraged. The committee points out that, elsewhere than in Britain, pension difficulties are a less serious obstacle and it expresses the hope that something will soon be done. The committee also complains that the Civil Service establishments are usually unable to help with removal expenses.

In practice, it seems that the migration of scientists from some parts of the government research machine in Britain is comparatively high. Thus in the five years 1961-65 inclusive, 159 members of the MRC staff, or about 19 per cent of the total, left for university employ. ment. Elsewhere than in the MRC, migration seerns to be much less frequent. The government establishmonts also appear to be able to recruit from the universities, at senior as well as junior grades, scientists whose numbers "almost exactly equal the losses". In the period 1961-65, 346 losses from government establishments to universities were almost exactly cancelled out by 342 recruitments. In practice, however, the MRC appears to be in an especially favoured position and recruited 29 per cent of its total staff from the universities in this period. This implies, of course, that other kinds of public research establishments were less able to recruit from the universities and the committee estimates that only 2.4 per cent of the research staff of other laboratories was obtained by recruitment from the universities in the period of five years.

The enthusiasm of the government departments for closer collaboration is plainly moderated, at least in part, by an awareness of the administrative difficulties thereby entailed. The Ministry of Technology, in its evidence to the Sutherland committee which necessarily refers to the period before amalgamation with the Ministry of Aviation, points out that the ten research stations on its strength would welcome closer association with the universities. Directors of establishments can receive research students without charging the universities for them. The National Physical Laboratory is one example of a laboratory which has undertaken to help neighbouring universities with teaching and which has found the courses provided to be valuable and stimulating for the staff. The United Kingdom Atomic Energy Authority is more free than most public laboratories to make special arrangements with universities and is in the habit of making spccial facilities such as reactors, accelerators and computers available to university scientists. The Authority says that during the year 1964-65 ten university scientists worked at each of Harwell and Aldermaston on reactors, end that moro than 80 scientists from universities were attached to Atomic Energy Authority laboratories for work on accelerators and computers. Altogether the Authority has appointed 140 consultants from 30 universities and has made a number of joint appointments with universities.
The research councils differ not so much in their willingness to collaborate with the universities as in their policy on supporting research. The Medical Research Council, with its device of creating research units which frequently entail joint appointments with the universities, is understandably the most closely embedded in the university system. But the Sutherland committee points out that five of the units and institutes of the Agricultural Research Council do not have arrangements with universities. At present it seems that something like 94 staff members and 135 research students at Agricultural Research Council laboratories are working for Ph.D. degrees.

The service departments are chiefly engaged with the universities by means of research contracts. The Royal Navy does, however, employ 70 university consultants in various ways and the loan of naval survey ships to university oceanographers is one example of collaboration. The Army boasts of relationships with university consultants and students even at the Chemical Defence Experimental Establishment. The Royal Air Force, of course, has the Meteorological Office under its wing and close links with the universities on matters such as meteorological research. The service departments said in their evidence to the Sutherland committee that security need not inhibit relationships with universities in "quite large sectors" of their research activity.

\section{Universities}

The Sutherland committee records somewhat laconically the conflict among the universities on the desirability of training Ph.D. students at government laboratories. Most universities, it appears, have some links with government ostablishments although geography is frequently against them. Opinion was divided on the desirability of parttime lecturers from government establishments, and three universities (Bristol, Brunel and Wales) say they would prefer full-time teachers to part-time. Altogether it seems that 21 universities are using staff from government establishments for research purposes, while a similar number uses them for teaching as well. Another nine universities use staff from government establishments to provide occasional lecture courses. It scems that all universities allow registered research students to conduct some research at government establishments, but that arrangements vary from place to place and that some residence is usually thought to be necessary. The universities of Birmingham, Bristol and Manchester argued to the committee that candidates reading for a $\mathrm{Ph} . \mathrm{D}$. degree should be regarded as trainees in research who require a continuous period of close supervision and help. Manchoster emphasized the importance of links between students and fellow research workers, while the ViceChancellor of the University of Birmingham (Sir Robert Aitken) was particularly anxious that government establishments might be in a position to "offer the recruitment bait of Ph.D. in addition to the drawing power of a substantial salary and attract potential university students thus prejudicing the future of research within universities".

As a sub-committee of the Council for Scientific Policy, the Sutherland committee cannot have the force of law. Its recommendations will in fact only acquire their full force when a number of other committees have reported on matters such as the mobility of scientific personnel and the loss of trained people from Britain to the United States. Moreover, it is clear that the universities will have to work out some machinery for taking a view on issues such as the proposal that the arrangements in the University of London for Ph.D. students at government establishments should be extended elsowherc. Another issue, not raised by the Sutherland committee but recently made topical by Professor P. M. S. Blackett (Nature, 213, $755 ; 1967)$, is that of whether the scientific work at present carried out in government establishments should remain there in porpetuity. 